IFAS Extension

\title{
Making Good Decisions: Media in the Lives of Young Children ${ }^{1}$
}

David C. Diehl and Stephanie C. Toelle ${ }^{2}$

\section{Making Good Decisions: A Series}

This article is an overview of a series of publications that addresses media and its effects on young children, from birth to age six. The series is designed to reach both professional educators and parents to provide the following:

- Research summaries about what we know about the effects of media on young children

- Tips for parents to help guide their decisions

- Internet resources for additional information on media issues

The series includes articles on the topics of:

- How Much Media are Young Children Experiencing?

- Media and the Physical Health of Young Children

- Television, Learning, and the Cognitive Development of Young Children

- Computers and the Development of Young Children

- Media and the Social Development of Young Children

- Advertising and Young Children

- Media Policy and Rating Systems for Young Children

Figure 1: Television is a powerful influence. (Photo Credit: Aaron Escobar)

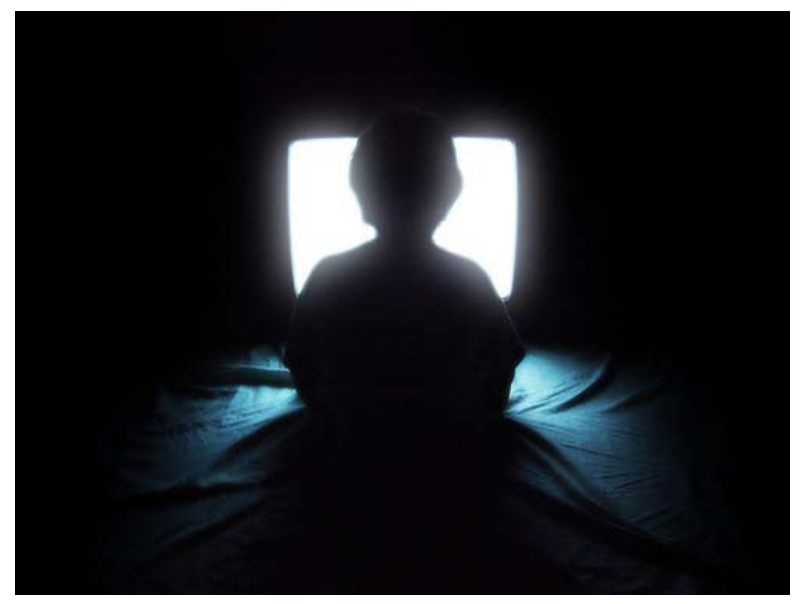

\section{Background}

American children are immersed in a culture of media, spending more time with television, computers, and other media than they do in any other activity except sleep. ${ }^{1}$ As a result, media are a major influence on children's physical, cognitive, and social development.

Media exposure has been linked to negative child outcomes such as overweight, poor language development, low grades, and aggression. ${ }^{2}$ However, exposure to positive media, such as educational television, has also been linked to enhanced learning and prosocial behavior as well. ${ }^{3}$ One of the primary lessons from research is that what children watch is perhaps the most important influence on their development. ${ }^{4}$

The American Academy of Pediatrics (AAP) recognizes the power of media to have both

1. This publication is FCS2290, one of a series of the Department of Family, Youth and Community Sciences, Florida Cooperative Extension Service, Institute o f F ood a nd A gricultural S ciences, $U$ niversity of $\mathrm{F}$ lorida. $\mathrm{P}$ ublication: December 2008 . Please $\mathrm{v}$ isit the $\mathrm{E}$ DIS Web $\mathrm{s}$ ite a $\underline{\text { http://edis.ifas.ufl.edu }}$

2. David C. Diehl, Ph.D., assistant professor, Department of Family, Youth and Community Sciences, Florida Cooperative Extension Service, Institute of Food an d A gricultural S ciences, U niversity of Florida, G ainesville, 32611 . S tephanie C. T oelle, extension ag ent IV, D uval C ounty E xtension, Jacksonville, FL. 
positive and negative effects on young children. However, because of their concerns about issues related to weight, learning, and aggression, the AAP has recommended:

- no television at all for children ages 0-2; and

- no more than 1-2 hours per day for older children.

Still, though, large portions of young children are being exposed to more television than is recommended by the AAP. ${ }^{6}$

\section{How Children Learn}

To guide parents in their decisions about children's media use, it is useful to start with what we know about how young children grow and develop in positive ways. How do young children develop the social, emotional, and cognitive skills needed to navigate this complex world?

Research on early brain development has established that while babies are born with billions of brain cells, positive interactions with their environment are critical to the development of neural pathways that enable positive development. ${ }^{7}$ To develop positively, infants and young children need:

- responsive, engaging,

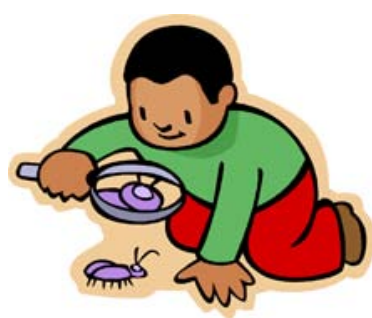
and stimulating interaction with people;

- exposure to rich language and sounds;

- the opportunity to explore the world and manipulate objects around them;

- the freedom and creativity that comes with play;

- guidance, structure, and support from adults; and,

- praise, affection, and positive feedback.

All of these things are best provided by other human beings, especially parents who care deeply about them. ${ }^{8}$
Summary of Research Findings

Research on the effects of media on young children presents several key findings:

- Many young children are exposed to television and videos on a daily basis. A recent study found that $83 \%$ of children under age two use screen media (television, videos, DVDs) on a typical day, and $66 \%$ of children aged six months to six years watch television every day. ${ }^{9}$ Television and videos are quite common in the lives of young children and can be an important influence on development.

- The content children experience matters. It is very clear that what children watch is critical. Children who watch more 'educational television' have shown benefits, while children who watch more 'entertainment television' have more negative outcomes. ${ }^{10}$ It is the messages being conveyed through television that are especially powerful in both positive and negative ways.

- The amount of television and computer usage matters. While media content has been identified as a clear factor in whether media effects are positive or negative, the amount of television and computer use matters as well. Research has identified a variety of negative consequences for young children who watch too much television or play too many video games, including academic performance, overweight, and aggression. $^{11}$

- The child's age and stage of development matters. As a result of their developing cognitive abilities, television and other images have different meaning and impact for children of different ages. ${ }^{12}$ While research has found benefits of educational programming for older children, there is little evidence that infants benefit from 'screen time.' All young children, but especially infants, need active and responsive interaction with their environment, which is best provided by people, not screens.

- Parents have the primary role of shaping the media experiences of their young children. Parents who take an active role in 
creating rules, boundaries, and expectations for media use are more likely to have children who benefit from media time. Further, parents need to engage in constructive communication with their young children while using mediathis establishes an ongoing dialogue about the messages children are receiving from media.

\section{What Parents Can Do ${ }^{13}$}

Media can serve as a resource for families, providing entertainment, enjoyment, and possible breaks for parents who need some time to themselves. However, to encourage positive development, parents need to manage their children's time with television, computers, and other media. Given the powerful influence of media on young children, parents have to figure out:

- what content they want their young children to be exposed to;

- how much 'screen time' they want their children to have; and

- what rules they are going to establish that will shape their children's development in a mediarich world.

To maximize the benefits of media for young children, parents can take the following steps:

- Keep the television and computer out of children's rooms. Children who have a television in their room watch much more television than those who do not and their viewing tends to be unsupervised.

- Set rules and boundaries. Families that have clear rules and expectations about media usage are more likely to control the amount of media exposure as well as the quality.

- Create family alternatives to television time. It is important to take some of children's media time and replace it with other family activities that encourage bonding, activity, and quality time together. Consider art projects, outdoor activities, sports, reading together, music, games, and other family activities.
- Choose positive programs for designated media time that provide learning opportunities for children. Identify educational materials and encourage your children to watch them. To learn more about recommendations for educational materials, visit www.kidsfirst.org or www.commonsensemedia.org.

- Talk with your children about media and work to build their 'media literacy.' Even young children can talk about media, its messages, and the reasons for family rules about television and computers. To learn more about strategies for increasing media literacy, visit www.medialit.org.

\section{Internet Resources for Parents}

The following are good resources for parents and professionals interested in how they can take control of the issue of media and how it affects young children.

\section{American Academy of Pediatrics Media Matters}

(www.aap.org/advocacy/mediamatters.htm): Provides an overview of AAP's campaign about media and its effects on children as well as advocacy and policy statements, public education brochures, and presentations on media issues.

Born Learning (www.bornlearning.org): Provides information on broader issues related to early learning for children and provides tips and resources for parents.

Center for Media Literacy (www.medialit.org): Provides resources on teaching children media literacy skills, specifically to critically question the messages that are presented to them (appropriate around 4-5 years old).

Center on Media and Child Health (www.cmch.tv): Created by Children's Hospital Boston, Harvard Medical School and Harvard School of Public Health, provides fact sheets for parents, teachers, and researchers.

Coalition for Quality Children's Media (www.kidsfirst.org): Provides reviews and 
recommendations on educational and informative movies, videos, audio, TV programs, and CDROMS.

\section{CommonSense Media}

(www.commonsensemedia.org): Provides resources and reviews of movies, TV shows, games, music, books, and web sites (includes ages 2-4 and 5-7, as well as older).

MediaWise (www.mediafamily.org): Provides fact sheets, newsletters, and other resources on media and family issues.

Parenting 24/7 (www.parenting247.org): This website from Illinois Cooperative Extension provides resources for parents, including news, information, video clips, and advice on parenting and family life from birth through the teens.

\section{PBS Children and Media site}

(www.pbs.org/parents/childrenandmedia): Provides resources on children and the media, including articles and tips for parents of preschoolers, grade schoolers, pre-teens, and teens.

PBS Kids (http://pbskids.org): Offers music, videos, and games for young children that are based on PBS shows, including Arthur, Cyberchase, Maya and Miguel, Reading Between the Lions, and others.

\section{Solutions for your Life}

(http://solutionsforyourlife.com): This is the Web site of University of Florida Cooperative Extension. It contains research-based resources on a variety of topics, including parenting, health and nutrition, financial management, and other family and consumer issues.

\section{Endnotes}

\footnotetext{
${ }^{1}$ Roberts, D., Foehr, U., \& Rideout, V. Generation M: Media in the lives of eight to eighteen year olds. Menlo Park, CA: Kaiser Family Foundation.

${ }^{2}$ The Future of Children (2008). Children and electronic media: Executive summary. The Future of Children, 18 (1).

${ }^{3}$ Children Now (2006). Children's educational television. Children and the Media Issue Briefs, 1, 1-8.

${ }^{4}$ Anderson, D., Huston, A., Schmitt, K., Linebarger, D, \& Wright, J. (2001). Early childhood television viewing and adolescent behavior: The recontact study. Monographs of the Society for Research in Child Development, 2001, 66(1, Serial No. 264).

${ }^{5}$ American Academy of Pediatrics (1999). Media education. Pediatrics, 104, 341-343.

${ }^{6}$ Mendoza, J.A., Zimmerman, F.J., Christakis, D.A. (2007). Television viewing, computer use, obesity, and adiposity in US preschool children. International Journal of Behavioral Nutrition and Physical Activity 4(44).

${ }^{7}$ Ramey, C., \& Ramey, S. (2004). How children learn and how parents can help. Plain Talk: The Newsletter for the Center for Development and Learning, 9 (2), 1-11.

${ }^{8}$ For more parenting resources, please visit www.parenting247.org or www.bornlearning.org.

${ }^{9}$ See Endnote \#1

${ }^{10}$ See Endnote \#3; See also Christakis, D., \& Zimmerman, F. (2007).

Violent television viewing during preschool is associated with antisocial behavior during school age. Pediatrics, 120, 993-999.

${ }^{11}$ Close, R. (2004). Television and language development in the early years: A review of the literature. London: National Literacy Trust.

${ }^{12}$ The Kaiser Family Foundation (2005). Issue brief: The effects of electronic media on children ages zero to six: A history of research. Menlo Park, CA: Kaiser Family Foundation.

${ }^{13}$ These suggestions were adapted from a variety of resources, including: www.cmch.tv; www.mediafamily.org; and www.aap.org/advocacy/mediamatters.htm.
} 